\title{
Research on Evaluation of College English Teaching Reform
}

\author{
Qinning $W u^{1}$ \\ ${ }^{1}$ Nanchang Institute of Science \& Technology, Nanchang, 330108 \\ 346591653@163.com
}

KEYWORDS: College English; Teaching Reform; Students

\begin{abstract}
University English is an important public foundation courses opened in Chinese universities and it is the most important way to obtain knowledge and skills in English. Our general university college English teaching in recent years has made remarkable achievements, the overall quality of students and teachers of English are gradually improving. However, there are still many problems in the current college English teaching, English proficiency of university graduates lacking. Scientific and technological progress and social development of the comprehensive English skills of university graduates put forward higher requirements, so also on college English teaching in colleges and universities has put forward higher requirements.
\end{abstract}

\section{Introduction}

Due to social progress and improve living standards, educational expectations of the people is also rising, China's higher education is a popular way to go, college enrollment is an irreversible fact. Increase the number of college enrollment college English teacher shortages make more severe, so relying on the existing teachers in accordance with the existing teaching model can not effectively complete the arduous task of teaching college English. In addition to increasing teachers' training, to enable them to more effectively carry out all kinds of teaching, it is more important is that the existing teaching objectives, teaching content, teaching methods, teaching methods, teaching evaluation and so a full range of reforms to make it adapt to the new education situation is conducive to new educational goals. China has joined the WTO, and the pace of global economic integration to speed up exchanges and cooperation is increasing worldwide, rely on the professional training of foreign language personnel can not meet the needs of domestic and foreign situation of rapid development. Therefore, the development of society on English proficiency of non-English major college graduates put forward higher requirements.

\section{Learning Situation Analysis of College English Learners}

University English Foundation Stage usually refers to four semesters of college English learning, from primary to four of the learning process. At this stage, the purpose of college English teaching is to train students with strong reading skills and a certain degree of listening, speaking, writing and translating. Since the examination system and examination form of influence, many colleges and universities one-sided emphasis on test scores, to focus on teaching students to lock as many test-taking strategies and methods, ignoring the students of English proficiency, and led to some widespread in Universities College English Teaching problems. In college English foundation stage of learning is completed, perhaps most students passed the English exam, but has no comprehensive 
ability to achieve the appropriate level. Many students can barely meet the test, but let them really to write, to translate, will encounter problems.

In listening and speaking, the majority of English teachers create an English environment attaches great importance to hear of the classroom, including English classes, a single set of listening course to practice their listening comprehension ability. But after all the time in the classroom is quite limited, students in after-school training and speaking ability is often easy to overlook, and some want to practice listening and speaking abilities of the students could not find effective ways and means, if a teacher does not in this to guidance, it will lead to weaker students heard about the phenomenon. Reading and writing are usually teachers and students put a lot of effort in training programs, but more limited reading material structure used, but also fixed problems with several types, choose the correct answer to follow the law; writing exercises are mostly used Material given by applying a fixed sentence or even a paragraph written. Over time, the students' reading and writing formed a similar "conditioned reflex" approach and remain at a fixed level, limited reading comprehension, writing essay also appears dull, lack of flexibility and new ideas.

Student personal factors have an important influence on the strength of the Comprehensive Capacity in English. First, student motivation and interest in learning a direct impact on student learning English in extracurricular invested time and effort. Doctrinal interest in learning English student initiative to find or create opportunities heard ability, reading and writing training, and to borrow or buy reading material, writing, listening and speaking guidance materials or recording materials and the like. Secondly, the students heard that personality differences and treat training attitude has a great impact on the listening and speaking skills, outgoing and extroverted personality bias in favor of the students listening and speaking skills training and improved, and inward and partial introverted student learning initiative nature and generally poor listening and speaking skills. Again, students learn concepts and learning strategies are different methods vary Learner learning different important reasons.

The current assessment methods as well as English are not conducive to students' English ability factors. For example, the above-mentioned reading and writing is easy to make students thinking stylized form-set to make learning English has been limited; oral test to a certain extent has not been given sufficient attention and most of the exam does not include oral test, which is bound to affect students enthusiasm and effectiveness of practice speaking; the lack of English learning process assessment, students focus on training and preparation of the questions, though to do a lot of questions, in the culture of English proficiency, but with little success.

\section{College English Teaching Strategies}

Reform of College English teaching, has long been of great concern to the community. College English teaching reform should focus on improving students' English comprehensive practical ability, which is the future of social development, education development are very forward-looking. English teaching reform should aim to achieve in college English teaching from examination-oriented education to quality education changes.

First, we must reform the current examination system and test mode. Language exam and language teaching are interrelated and influence each other, "partnership", therefore, the impact of testing on teaching is often decisive. To make the test really effectively promote English teaching, play good exam backwash effect, we need to reduce the amount of objective questions, increasing the real language of the test material, so that the examination to become a real scale test students' comprehensive language ability. 
Secondly, the teaching process to strengthen students' language input and absorption. The existing common situation is that students in order to pass the CET, put a lot of time to research questions, grammar, meaning discrimination and on examination skills. In teaching, there are also isolated, the sake of discussion, the endlessly doing exercises phenomenon. On the surface, scores improved, in fact, the overall level of English and no substantial improvement. More worth pondering is that supposed to be lively and interesting learning English, for many students, become, tedious chore machinery. Not a lot of input and absorb authentic language, blindly rely on the sea tactical, learners can never acquire language skills and communication skills, and no gain on language awareness. Therefore, in teaching, students read English newspapers, books and other original habit is to develop language sense, an important means to improve students' comprehensive language skills, but also the lack of steps is not.

Third, in order to fundamentally improve their listening, we should start from the source, modify the requirements of college English teaching, strengthen Listening Teaching. Students under the current framework, "the preliminary hearing ability" has been unable to meet the current community complex, high-quality personnel requirements. Training integrated talent is imperative. In addition, hearing tests must contain written part. Four examinations despite an increase in compound dictation, but because with the original text, the students understand the need to focus the missing words and sentences can be, so that students understand the training capacity of the chapter can not play the best results.

Fourth, it is necessary to set up Chinese language courses to students, the basics of translation, Chinese and Western cultures contrast other courses. Through these courses, students can enhance the sensitivity and understanding of different cultures, students 'ability to express Chinese culture, so as to gradually improve the students' level of translation.

Fifth, improve writing skills, you must first have a solid vocabulary and grammar basic language skills. If the lack of practice of language, lack of accumulation of language material, and the material in the memory of only about a lack of accuracy, which would lead to only deal with consequences of multiple-choice questions and writing mistakes. Thus, college English teaching should enable students freed from a large-scale objective multiple-choice questions, and more accumulation of vocabulary, grammar solid learn, appreciate and even recite some of the more beautiful articles or paragraphs, lay the basic language skills. In addition, to enable students to write is necessary because write more, natural expression will be more skilled, more and more fluent. In a lot of reading on the basis of write, it is to improve students' English writing skills important and effective way.

\section{Factors Affecting College English Teaching and Learning Outcomes}

In the late 1980s to the early and mid-1990s, a large number of formal English language skills training graduates joined the ranks of college English teachers, college English teaching so that to achieve a rapid development. It was also during this period, the development of the situation of college graduates put forward higher requirements. However, most college English teaching universities still dominated reading, ignoring the listening, speaking, reading, writing, translation ability to use the train. National College English CET on college English teaching also had a huge impact, resulting in a large area of teaching to the test. Most students cope with all kinds of good written exam, even a high score, but lack the ability to communicate effectively in English, so that college English teaching and learning, although time-consuming and labor-intensive but can not meet the needs of social development. 
There was a long period of time, English teaching and research university focused on finding the best way of teaching, many teaching methods continue to emerge, such as the 1950s, said the emergence of audiovisual law or heard law, 70 years appeared cognitive approach, communicative France, and later appeared in succession silence law, systemic reaction, and so on. However, with so many teaching methods, the efficiency of college English learning has not significantly improved. Thus, the study of college English teaching experts, scholars and university teachers in teaching English gradually realized that an important question: external factors just learning teaching methods, but largely play a decisive role in college English learners Internal factors. So accordingly, the English teaching and research universities focus has gradually shifted from "how to teach" to "how to learn", a gradual shift from the study "Teachers" and "teaching" to "student" and "learning."

After years of research, most researchers believe that an important factor in causing individual differences in age, intelligence, language aptitude, cognitive styles, personality traits, motivation, learning strategies and learning concepts like. These factors can be divided into the learner's own two categories, one is controllable factors, it refers to the student's own efforts can change factors, such as motivation, learning concept, learning strategies; the other is uncontrollable factors, those factors depend on the student's own efforts can not be changed, such as intelligence, aptitude, personality traits, past student of English, teachers quality. Study individual differences in variable factors, such as what kind of learner learning strategies, with what kind of motivation to learn, how to treat themselves, can control themselves, how to blame their own reasons for success and failure, etc., is the real concern individual learner differences and their change, really practical.

\section{Conclusion}

College English teaching reform long way to go, as long as all people care about college English teaching reform of unremitting efforts, China's college English teaching will certainly move towards a bright and splendid future for the community to train and provide more people with a solid basic skills and general English ability to use talents.

\section{REFERENCE:}

[1]Alderson,. Language Test Construction and Education [M]. Beijing: Foreign Language Teaching and Research Press, 2000, 103.

[2]Arends, R. Learning to Teach [M]. New York: McGraw Hill Book Company, 2001, 56

[3]Bremner, S. Language Learning Strategies and Language Proficiency [J]. the Canadian Modern Language Review, 1999, 5, 24.

[4]Cohen, A. D. Strategies in Learning and Using a Foreign Language[M]. Beijing: Foreign Language Teaching and Researching Press, 2001, 153.

[5]Herbert, W. S. Second Language Research Methods [M]. London: Oxford University Press, $1999,168$. 